\title{
Navigating ethnicity, nationalism and Pan-Africanism - Kimbanguists, identity and colonial borders
}

\begin{tabular}{|c|c|}
\hline \multicolumn{2}{|c|}{$\begin{array}{l}\text { Author: } \\
\text { Mika Vähäkangas } 1,2,3\end{array}$} \\
\hline \multicolumn{2}{|c|}{$\begin{array}{l}\text { Affiliations: } \\
{ }^{1} \text { Center for Theology and } \\
\text { Religious Studies, The Joint } \\
\text { Faculties of Humanities and } \\
\text { Theology, Lund University, } \\
\text { Lund, Sweden }\end{array}$} \\
\hline \multicolumn{2}{|c|}{$\begin{array}{l}\text { 2Desmond Tutu Centre, } \\
\text { Faculty of Arts and } \\
\text { Humanities, University of } \\
\text { the Western Cape, Cape } \\
\text { Town, South Africa }\end{array}$} \\
\hline \multicolumn{2}{|c|}{$\begin{array}{l}\text { 'Department of Practical } \\
\text { Theology and Missiology, } \\
\text { Faculty of Theology, } \\
\text { Stellenbosch University, } \\
\text { Stellenbosch, South Africa }\end{array}$} \\
\hline \multicolumn{2}{|c|}{$\begin{array}{l}\text { Corresponding author: } \\
\text { Mika Vähäkangas, } \\
\text { mika.vahakangas@ctr.lu.se }\end{array}$} \\
\hline \multicolumn{2}{|c|}{$\begin{array}{l}\text { Dates: } \\
\text { Received: } 15 \text { Mar. } 2021 \\
\text { Accepted: } 16 \text { Apr. } 2021 \\
\text { Published: } 06 \text { July } 2021\end{array}$} \\
\hline \multicolumn{2}{|c|}{$\begin{array}{l}\text { How to cite this article: } \\
\text { Vähäkangas, M., 2021, } \\
\text { 'Navigating ethnicity, } \\
\text { nationalism and Pan- } \\
\text { Africanism - Kimbanguists, } \\
\text { identity and colonial } \\
\text { borders', HTS Teologiese } \\
\text { Studies/Theological Studies } \\
\text { 77(3), a6620. https://doi. } \\
\text { org/10.4102/hts.v77i3.6620 }\end{array}$} \\
\hline \multicolumn{2}{|c|}{$\begin{array}{l}\text { Copyright: } \\
\text { C 2021. The Authors. } \\
\text { Licensee: AOSIS. This work } \\
\text { is licensed under the } \\
\text { Creative Commons } \\
\text { Attribution License. }\end{array}$} \\
\hline \multicolumn{2}{|l|}{ Read online: } \\
\hline 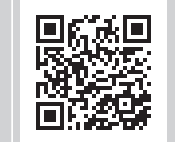 & $\begin{array}{l}\text { Scan this QR } \\
\text { code with your } \\
\text { smart phone or } \\
\text { mobile device } \\
\text { to read online. }\end{array}$ \\
\hline
\end{tabular}

The Kimbanguists, whose church is based on the healing and proclamation ministry of Simon Kimbangu in 1921 in the Belgian Congo, challenge colonially defined borders and identities in multiple ways. Anticolonialism is in the DNA of Kimbanguism, yet in a manner that contests the colonially inherited dichotomy between religion and politics. Kimbanguists draw from holistic Kongo traditions, where the spiritual and material/political are inherently interwoven. Kimbangu's home village, Nkamba, is the centre of the world for them, and Kongo culture and the ancient kingdom form the backdrop of the Kimbanguist view of the new eschatological order to come. The reunification of the kingdom from the two Congo states and Angola will mark the inauguration of the new era. This will not, however, mean a splintering of the Democratic Republic of Congo but rather a removal of the colonial borders. That hints towards a Pan-African vision of a united Africa and even a universally united Black race that will play a central role in the eschatological salvation historical drama. The Kimbanguist vision also contains global dimensions, and their view of borders and identities is like Nkamba-centred ripples in water. This vision wipes away colonial borders and relativises ethnic, national and racial identities whilst strongly subscribing to a salvation historical narrative that places Africa and Africans in the centre.

Contribution: This article contributes to the study of nationalism as well as of African Instituted Churches. The analysis of how the Kimbanguists relate to (Kinshasa) Congolese nationalism, Kongo ethnic identity and Pan-Africanism as well as of their global missional views reveals layers and complex patterns of relationship between all these. What facilitates the simultaneous subscribing to all these layers is an openness of identities (Kimbanguist national, ethnic, etc.), as well as a tendency to see the world as consisting of interdependent areas and human communities with their holy city, Nkamba, in the centre.

Keywords: Kimbanguism; African Christianity; nationalism; Pan-Africanism; decoloniality; Kongo religion; religion and politics; African Instituted Churches; borderscapes.

\section{Introduction ${ }^{1}$}

The aim of this article is to analyse the ways in which the Kimbanguist Church (Église de Jésus Christ sur la terre par son envoyé spécial Simon Kimbangu [the Church of Jesus Christ on Earth through His Special Envoy Simon Kimbangu]) and Kimbanguist Christians deal with ethnic and national boundaries and thereby reveal their way of producing identities - Kimbanguist, African and Christian. I begin by presenting my approach to national, linguistic and cultural borders and proceed from there to a brief introduction of Kimbanguism, followed by an analysis of their way of negotiating Kongolese, Congolese, African and Christian identities.

This article builds on ethnographic data - observations recorded in field work diaries (Fwd), recorded interviews (I), a focus group interview (Fgi) and written data such as books, internet sources, academic theses and unpublished manuscripts. I have been in contact with Kimbanguists for almost 20 years, mostly in Sweden and Finland, but I have also visited Kinshasa and Nkamba for research purposes. My primary purpose has been to study Kimbanguist theology and cosmology, which means that the data on which I build my analysis comes from written sources as well as informal discussions and from between the

\footnotetext{
1.The research has been carried out in compliance with the Swedish law on sensitive personal information, which means, amongst others, that the project has undergone an ethical clearance process, and the research follows the principles of informed consent, anonymity and non-harm to the research participants.
}

Note: Special Collection: New Landscapes in Identity: Theological, Ethical and Other Perspectives, sub-edited by John Klaasen (University of the Western Cape). 
lines of statements not primarily intended to express opinions about identities.

\section{On national, linguistic and cultural borders}

That African national borders were drawn by the colonialists with no respect for cultural and linguistic realities on the ground is repeated almost any time national borders are discussed in Africa. Whilst this is an historical and political fact, there also often seems to be the implied idea that the colonialists enjoyed national unity and properly placed borders in Europe. However, rather than naturally existing, nations have been produced even in Europe (e.g. Anderson 2006).

Inasmuch as European borders seem to tally with cultural and linguistic borders, it is often an outcome of genocide like the Holocaust, forced migration like in 1923 between Greece and Turkey or in Central Europe after the Second World War, coercion and faking national unity. At the time of the revolution in late 18th-century France, only half of the population could speak French and only one in 10 fluently (Hobsbawm 1992:60). Similar developments have taken place all over Europe. Finally, there is also a tendency to conceal national minorities and their languages, which creates a faked sense of national unity.

National borders marking state sovereignty are an expression of violence and also an act of violence as such. As markers of territorial sovereignty, they refer to the state monopoly of violence within the territory. The term 'territory' contains also a reference to violence: in Latin, it may have the same root as 'terror', stemming from the fact that the owner of a territory is the one with means to frighten intruders away (Elden 2009:xxviii-xxx). Borders are not only markers of violence but also acts of violence in the sense and to the extent that they forcefully separate people and areas from each other (Brambilla \& Jones 2020:288-292). Territorial state borders spill through the concept of national state over to cultural and linguistic borders.

The African national borders as a form of violence are thus not an exception. What is somewhat exceptional with African borders is that their drawing was so abrupt, and the local populations, even the elites, often played absolutely no role in it.

National borders cannot follow cultural-linguistic borders because the latter are fuzzy. Quite often, before the codification of languages in written forms, often in relation to the translation of the Bible, there is a gradual shift through dialects and pidgins between languages. Even sharp linguistic borders are often violent, resulting from the repression of minority languages and deviating dialects.

However, all borders also contain the dimension of unification within the bordered area - violent or non-violent (Brambilla \& Jones 2020:289, 292). States forge unity - political, administrative and, in the case of ethnonational states, also linguistic and cultural unity. In both cases, the insiders of the ethnicity and/or language form an imagined community binding the members together.

Thus, to conclude, national and linguistic-ethnic clear-cut borders are constructed in a negotiation of power. In colonial situations, no representatives of the people living in the area, not even the elite, are involved. Additionally, the nature of borders, be they national or linguistic, is violent. This is because borders are there for control and exclusion. This is a reality that many Africans are painfully aware of. In the following, I will analyse how the Kimbanguists decolonially reclaim their power of negotiating borders - national, ethnic and religious ones - and reconstruct them, thereby constructing the dimensions of their identity as Africans and Christians. In this manner, they participate in the shaping of political ideologies that facilitate the construction of imagined communities - in this case, ideally without violence.

\section{Kimbanguism as an African reaction to the Gospel and colonialism}

The Kimbanguist church is amongst the largest African Initiated Churches, with members probably numbering over 20 million. $^{2}$ It has a very strong following amongst the Bakongo and neighbouring ethnic groups, but its membership extends beyond that and is global, with a heavy concentration amongst the African diaspora. The church is centrally governed by the chef spirituel, Simon Kimbangu Kiangani, who is the founding prophet Simon Kimbangu's grandson. There are numerous splinter groups that also consider Simon Kimbangu as their prophet or saviour. The Kimbanguist church has recently been expelled from the World Council of Churches (WCC) as heterodox because of its teaching that Simon Kimbangu was an incarnation of the Holy Spirit (Simon forthcoming).

Simon Kimbangu was born in about 1889 in the village of Nkamba in the Lower Congo of the so-called Congo Free State. ${ }^{3}$ This colony was the private property of the Belgian king Leopold. 'Free' in the name denoted that companies had practically complete freedom to enslave, murder and maim people for profit in their concession areas. ${ }^{4}$

Kimbangu was in contact with Christianity from his early childhood on because a Baptist missionary station was located nearby. As a young man, Kimbangu experienced being called by God to heal and preach. His ministry in Nkamba soon attracted immense crowds of Africans who came for healing. He preached the Gospel and healed the sick. His whole ministry lasted barely half a year in 1921,

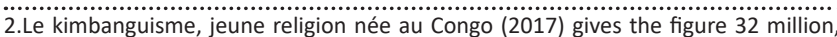
whilst some Kimbanguist sources mention 17 million (e.g. the chef spirituel [church leader]; Fwd Nkamba 2015-07-10:6).

3.This is his year of birth as estimated by historians; the Kimbanguists conside 12 September 1887 as his birthday (Mokoko 2017:62).

4.Nzongola-Ntalaja (2002:15-26); Ustorf (1975:53-55); Likaka (2009:85-106); Sanderson (2000:332-333). These atrocities were reintroduced to popular discourse by Hochschild (1999). 
because the Belgian troops soon came after him, and after a short period of underground activity, he surrendered himself into the hands of the colonialists. He was condemned to death for high treason after a highly irregular military court case, one of the irregularities being a lack of a defence lawyer. By then, King Leopold's African businesses had become an embarrassment for the colonial movement, and the other colonisers shed light on atrocities in the Free State to distract attention from their own felonies. Thus, when Protestant missionaries raised the alarm on the Kimbangu-case - he was a convert of theirs, after all - international attention was secured. Simon Kimbangu's capital punishment was transformed into a life sentence, which he served largely in solitary confinement until his death in $1951 .^{5}$

Were the Belgians totally mistaken in considering Kimbangu as a political threat? Today's Kimbanguists usually emphasise the apolitical nature of his vision and ministry, which often goes hand in hand with arguing for the utter injustice and even meaninglessness of the conviction (Diangienda 1984:67; Fwd Stockholm 2014-11-09:14). At the same time, however, one of the most repeated of his prophesies is that the black will become white, and the white will become black' (Fwd Nkamba 2015-07-13:13). Even if these words are interpreted in different ways, the common denominator in interpretations is that Africans will no longer be under white people, be it in terms of politics, economy, technology or anything else (Diangienda 1984:82; Mangoyo n.d.:6; Martin 1971:116; Mokoko 2017:66; see also Ustorf 1975:186-187). That was a dangerous message from the point of view of the colonialist exploiters. It was in their interest to keep the population so subdued under tyranny that they would have no hope for the better. In that sense, the colonial authorities' fear of Simon Kimbangu was understandable, especially considering the colonial administration's constant paranoia (Hunt 2016).

Kimbangu never encouraged violent forms of resistance, but still, after his imprisonment, his followers were divided into different streams: the pacifist and (at least seemingly) apolitical Kimbanguists and more militant Ngunzists, who agitated for independence from the colonial yoke. ${ }^{6}$ What made even the pacifist Kimbanguists only seemingly apolitical is the fact that in the Kongo worldview, politics and religion are inseparable (see Diangienda 1984:122, 127, 166-167). In the kingdom of Kongo, the king had sacral duties (Mokoko 2017:18-19). The first notable Christianinspired prophet, Kimpa Vita, saw the restoration of the Kongo kingdom as her major goal and attempted to do just that until she was burned at the stake in 1706 (Thornton 1998). Many Congolese therefore see her as the first independence fighter against colonialism Portuguese, at that time (see Covington-Ward 2016:198; Mokoko 2017:43-52).

5.On Simon Kimbangu's life and work, see Diangienda (1984) for an inside view and Ustorf (1975) for a historical-critical outsider's view.

6.Ustorf (1975:188, 198-208, 215-220); Andersson (1958). Ngunza is Kikongo for 'prophet'.
Today, Simon Kimbangu is seen primarily as a religious figure by the Kimbanguists whilst the larger society sees him as a notable early figure in the struggle for freedom (see Mokoko 2017:76-78, 229). The Kimbanguists acknowledge his importance for the independence movement (Diangienda 1984:7) and the overlapping of the independence movement's and the Kimbanguists' goals, whilst emphasising the mutual independence. The first church leader, Simon Kimbangu's son Diangienda, expresses the basic argument well: 'Even if the goals are shared - in terms of freedom and independence between us and the politicians, our struggle is not theirs'. ${ }^{7}$

It is noteworthy that the first satellite sent by the Democratic Republic of Congo (DRC) into outer space was called 'Kimbangu'. ${ }^{8}$ Kimbanguist reactions to the political attention to the foundational figure are divided. On one hand, the Kimbanguists are clearly flattered by the attention, but on the other hand, this attention contains the risk of appropriation of their religious front figure for political purposes.

However, the inappropriateness of separating or even distinguishing religion and politics in the Kongo world becomes apparent in the Kimbanguist emphasis on placing Simon Kimbangu on a continuum of the Kongo prophetic tradition, beginning with Kimpa Vita (Bazizidi 2012:185; Kina-Kuntala 2009:7; see also Covington-Ward 2016:198; Mokoko 2017:45-52; Mpassi 2009:7). This can be well argued from a historical and cultural perspective, but it makes him inevitably political in the colonial gaze.

\section{Kimbanguism as a Kongolese and Congolese African Christian movement}

European colonialism was one of the major causes of the demise of the Kongo kingdom. Portuguese slave traders were able to benefit from the Kongo internal divisions. Later, when European colonialism was intensifying, the cultural area of Kikongo speakers was distributed between three looters: Portugal, France and King Leopold. This division continues as an open wound in the minds of the Bakongo, forcing them to live in three countries: Angola (where the ruins of the ancient capital Mbanza Kongo are located), the DRC (Congo Kinshasa) and the Republic of Congo (Congo Brazzaville) (Mokoko 2017:18). There are hopes for the political reunification of the Bakongo under one political entity. ${ }^{9}$ This is a complicated issue in the sense that changing the colonial borders between African nations has been

7.Diangienda (1984:179): 'Même si les objectifs sont communs - à savoir la liberté et indépendance - entre nous et les politiciens, notre lutte n'est pas la leur'. (The English translation above, M.V.) See also Kina-Kuntala (2009:105-106) on balancing between the apolitical religious and anticolonial political dimensions. According to Melice (2001:38-39), Kimbanguism emphasised its apolitical characte at the time when ABAKO (Alliance des Bakongo/Alliance of the Kongo people), which began as a cultural association, turned increasingly political.

8.A dummy of the satellite was presented to the chef spirituel in Nkamba during my fieldwork. Fwd Nkamba 2015-07-12:12-13.

9.For example, the ABAKO party proposes redrafting the borders, and Bundu dia Kongo [Gathering of Kongo], a more radical political group, focuses its religious message on this reunification. See Kilansi Kia Kongo Dia Kati (2018); CovingtonWard $(2016: 2,194-195,208)$. For the Bakongo, ethnic identity tends to dominate over national belonging. Fwd Kinshasa 2015-07-06:7-8. 
avoided until recently because it would open a can of worms, possibly leading to armed conflict. Additionally, it is questionable whether the members of other ethnicities would feel comfortable with a united and strong Bakongo community, which might weaken the relative position of the others. Furthermore, the fact that in Angola and the Congos, the administrational languages differ - French and Portuguese - makes the equation more difficult to solve.

Kimbanguism is distinctively a Kongo-based movement. Its original and holy language is the language of Simon Kimbangu, Kikongo. Even though other languages are also used, Kikongo holds a special place and is sometimes depicted as the language of the future eschatological kingdom. ${ }^{10}$ Most of the central religious terminology is in Kikongo, but the lyrics of the revealed songs (chants captés) allegedly coming directly from God are in various languages (Molyneux 1990:153, 156-157, 161-162). Furthermore, the religious praxis is thoroughly, and most probably consciously, multilingual. Therefore, the Kikongo linguistic preference is not exclusive in the sense of putting off people of other linguistic backgrounds. The practical purpose of communication takes precedence over the theological, cultural and historical preference for Kikongo. Therefore, despite the Kongo cultural predominance in his presentation of the Kimbanguist history and faith, the then-chef spirituel Diangienda (1984) points out that the Kimbanguists 'respect the culture and identity of every human group' (p. 286).

By placing Kimbangu in the continuum starting with Kimpa Vita, the spiritual genealogy is also clearly anchored in the Kongo heritage, and Kongo becomes a specific location of God's revelation (I Stockholm 2015-05-24:6-11). Simon Kimbangu's symbolic world - actions, sayings and the material objects related to his ministry - portray a confluence of Kongo and biblical imaginary. This is hardly surprising, considering that the Mukongo Simon Kimbangu had a Baptist biblicist background. A good example of this confluence is the staff (mvuala) that he cut of wood near Nkamba (Fwd Nkamba 2015-07-15:6). This staff has supernatural qualities, so that it confers upon its holder sacred power, and it can even move to places by itself (Fwd Nkamba 2015-07-14:10; Diangienda 1984:84-85; MacGaffey 1969:143; see also Mokoko 2017:20, 158; Pemberton 1993:217). Its equivalents are clearly both the Kongo royal staff as well as Aron's staff during Israel's wandering in the wilderness (MacGaffey 1969:134; Melice 2001:37; Mokoko 2017:67-68). Both had supernatural qualities. However, the fact that Kimbangu's staff clearly relates to his elevated status and authority makes it resemble a royal staff rather than that of Aron. In Kimbanguist oral narratives, the Belgians are said to have unsuccessfully attempted to find the staff to harness its powers (Fwd Ngombe Kinzuka 2015-07-15:1-2). The staff represents the king fully, and therefore it is not surprising that Simon Kimbangu's (already deceased) three sons are called zimouala (plural of mouala) (MacGaffey 1983:183; Mangoyo 2003:25; Melice 2001:46-47).

Whilst the Kongo spiritual-cultural heritage's ubiquity can be vaguely felt most of the time, ${ }^{11}$ there are only a few explicit expressions of it. ${ }^{12}$ One such is the not-so-seldom-heard prayer for 'Kongo Kinshasa, Kongo Angola and Kongo Brazzaville', and a divinely inspired song puts the following words in the mouth of the chef spirituel of the time, Dialungana:
Mr. President of the [Democratic Republic of the] Congo
Mr. President of [the Republic of the Congo] Brazza
Mr. President of Angola,
You must find an agreement ... (Mokoko 2017:239; see also pp. 187, 239-240, 245)

Another, very visible, expression of the desire for Kongo reunification is the building of a major construction, the house of the three kings, for the presidents of the three countries in Nkamba. The idea is that the three presidents would come and visit Nkamba at the same time and stay in that building together. ${ }^{13}$ There is a strong implication of the historical undivided Kongo kingdom, whose borders were constantly shifting but practically always at least reached the area of these three countries of today. The prayer and the song do not make any claims about specific areas belonging to the Kongo kingdom but only stress the unity of the three (see Mokoko 2017:187, 239-240, 245). On the other hand, the house of the three kings implies a different approach. The authority of the Kongo kings is now divided between the three presidents in spite of the fact that one could not imagine even in their wildest dreams that at any given time all of them would come from a Kongo cultural background. ${ }^{14}$ Yet, they represent the authority and the hope for all major Kongo areas being once again united in one country. This is an implicit protest against the borders as violence - this time against the Kongo ethnic identity. These hopes are linked to eschatological views where the Kingdom of God and the reunited Kongo kingdom float together to become the end of times and the start of God's reign (see Mokoko 2017:245).

However, borders are not only divisive violence; for those inside them they are also a unifying factor (Brambilla \& Jones 2020:289). The Kimbanguist hope of unification does not imply any splintering of the existing countries, thereby losing the uniting function of the colonial borders.

11. However, Fwd Kinshasa 2015-07-06:7-8 contains open discussion about this. See Martin (1971:167) on the ABAKO party and the fact that Simon Kimbangu's son, Charles Kisolokele, was active in it (p. 173). See also Molyneux (1990:174); Covington-Ward (2016:132-133). Diangienda (1984:167) discusses ABAKO but does not point out his brother's involvement in it, even if pointing out his position as a cabinet minister (p. 196).

12.According to Mokoko (2017:181), Simon Kimbangu never emphasised the Kongo ethnic element. Furthermore, Covington-Ward (2016:105) maintains that increased ethnic identification is a later development.

13. Mokoko (2017:186); Fwd Nkamba 2015-07-14:10; 2015-07-15:3. This kind of a meeting, albeit at an ambassadorial level, took place in 1999 (Mokoko 2017:238-239).

14.On the balance concerning ethnicity, see Mokoko (2017:189-192). 
This becomes especially evident in the case of the DRC. Even the DRC is regarded in Kimbanguism as a holy land and may not be divided. Simon Kimbangu's journey of suffering and death was practically a tour all around the Belgian Congo. Firstly, he was taken from Nkamba to the nearby colonial administrative centre Thysville (MbanzaNgungu) for trial and from there to Leopoldville (Kinshasa) to commence a boat journey upcountry, snaking via the north towards the east and eventually with different forms of travel to Elisabethville (Lubumbashi), the major centre of southern Belgian Congo. He spent the rest of his life in prison there and was eventually buried there, as well. After Congo gained its independence in 1960, Simon Kimbangu's body was exhumed and brought on a truck by a road running close to the Angolan border in the west. In this manner, he had made as complete a tour around the country as possible, given the infrastructural constraints. This circular tour is interpreted amongst the Kimbanguists as divine evidence of the necessity to keep the DRC united (Fwd Kinshasa 2015-07-06:6; Fwd Nkamba 2015-07-10:8; see also Mokoko 2017:228).

What becomes evident from the above is that the Kimbanguist vision is not to restore the Kongo kingdom and secede from the DRC, Angola and Congo Brazzaville but rather to unite the three. In this manner, the colonial borders are not only seen as a divisive negative factor but also a uniting reality between the different ethnicities (see Kina-Kuntala 2009:61). This unifying approach becomes visible also in the possibly consciously vague use of the terms 'Kongo' and 'Congo'. You cannot hear the difference, and because one does not define the meaning, the hearer is free to interpret it as either or both. For the Mukongo, the term boosts their ethnic identity yet still includes all Congolese ethnicities.

One often gets a strong feeling that the difference between 'Kongo' and 'Congo' is not even important because of the conspicuous lack of definition when people speak of 'Kongo' or 'Congo', with only the context of the word sometimes revealing that it is a question of one or the other. Furthermore, Kimbanguist literature does not always make the distinction in spelling like recent academic studies do. Clear references to 'Kongo' are often spelled with a C. ${ }^{15}$

The centre of the world is Nkamba, at any rate. Adam and Eve were created there, at an exact spot that is shown to visitors. ${ }^{16}$ Simon Kimbangu was born and carried out his ministry there. Today's Kimbanguists believe that he is an incarnation of the Holy Spirit (with one of his three sons as another, and the present church leader and grandson, Simon Kimbangu Kiangani, as Simon Kimbangu's reincarnation and thereby an

15.Bazizidi (2012:256) refers to the Kingdom of Kongo and the DRC as possible locations of Kimbanguist eschatological hope, expressing the ambiguity. For example, Mokoko (2017:187) quotes a divinely inspired song in translation, which clearly refers to the Kongo kingdom as 'the initial Congo', spelled with a $\mathrm{C}$ by Mokoko.

16.The chef spirituel confirmed this to me in person. Fwd Nkamba 2015-07-16:6 See also Mokoko (2017:182-184, 187, 191); Fwd Nkamba 2015-07-10:9-10 2015-07-14:9. A part of the Kimbanguist argumentation is that even scientific evidence supports their position, because humans originally stemmed from Africa. incarnation of the Holy Spirit, as well). Additionally, according to the Kimbanguist faith, at death every human being will climb (obviously spiritually) the stairs to the holy city on the hill, Nkamba, the New Jerusalem [Yelusalemi dia Mpa / Nouvelle Jerusalem] ${ }^{17}$ In their eschatological vision, the Kimbanguists expect Nkamba, the Congo and Africa to play a central role in the last things, to be a vessel of salvation and an asylum for humankind, like Noah's ark (Fwd Nkamba 2015-07-14:5). Thus, in Nkamba you would find the beginning and the end of human history.

The Kongo area, and by extension, the Congos (including Angola) are the holy country where this holy city (or village) is located. Instead of approaching these countries as administrative units, one could rather see them through their relation and proximity to Nkamba. Nkamba is the navel of the world. From the navel, its uniting function proceeds like ripples in the water: to the Kongo area, to the Congos, Africa and the ends of the earth. This imaginary is rather biblical if one just replaces the old Jerusalem with the new.

In this manner, the Kimbanguists seem to propose that the borders be transformed into borderscapes, from dividing lines into areas of contact and exchange. At the same time, Congo would turn from a territory from which to terrify away outsiders into the home of the Bakongo. In the Kimbanguist-Kongo culture of hospitality, a home is a place open for friends and visitors. A guest is welcomed to eat and feel at home whilst respecting the home of the host.

\section{Being Pan-African and Christian}

The fact that the colonial borders are not supposed to be replaced by ethnically based borders is in itself a nod towards Pan-Africanism. In fact, the colonialists accused Simon Kimbangu and Kimbanguists of Pan-Africanism. No matter the unifying ideas concerning Africans Simon Kimbangu may have had, he and his closest followers probably had no connection to Pan-Africanists. However, because Pan-Africanism was clearly a political movement directed against colonialism and racism, the colonialists in the Belgian Congo were alarmed about even slight hints towards such thinking and action (cf. Nzongola-Ntalaja 2002:49; Ustorf 1975:159-163).

What is clear, however, is that both Simon Kimbangu and his followers, including those today, pay special attention to the issue of race (see e.g. Molyneux 1990:167). It is hard to see how it could be otherwise, because the Congolese at the time of Simon Kimbangu were oppressed as black Africans. People of other colours, who were mainly white, were at the other end of the colonial pecking order. It is difficult to imagine that Simon Kimbangu would have had the fate he had if he had not been a black African. Likewise, racism and inequality have been the defining features in encounters between Africans and Europeans even afterwards. Other movements starting in the same area 17.Janzen \& and MacGaffey (1974:132) (from Diangienda's "'ioyalty to Jerusalem", 1959); Fwd Nkamba 2015-07-13:10-11; 2015-07-16:6; Mangoyo (2000:26); Bazizidi (2012:71). 
during colonial times also have (had) a strong racial orientation. The Antonian movement led by Kimpa Vita believed that Jesus and the apostles were black and had lived in Mbanza Kongo/Sao Salvador, the Kongo kingdom capital (Thornton 1998). The Ngunzists shared the Kimbanguist roots and their attention to race but chose a more militant approach (Andersson 1958).

In the Kongo cosmology, where nothing happens by chance, the Africans' miserable fate begs a metaphysical explanation. One such is the myth of Ham's / Canaan's curse (Gn 9:20-25). In this biblical narrative, Noah curses his son Ham's offspring because he shamed Noah. In the colonial interpretation, Ham was dark skinned. This interpretation has long historical roots, and this fact has led to a blame game on who is the culprit for introducing the racist interpretation of this text (Knust 2014:399-406). Therefore, black people would be servants and slaves of white people forever. The Kimbanguists, instead of rejecting this interpretation, embraced it and assumed a special African responsibility for sin (Fwd Stockholm 2017-07-09:4). This would, in turn, be the explanation of the fate of Africans and also for the coming of the incarnation of the Holy Spirit just in Africa. Simon Kimbangu came to redeem his people from this special curse. In this manner, the myth used to oppress the Africans is subversively turned upside down, and it becomes proof of Africans' central role in salvation history. Adam and Eve, created in Nkamba, were black (Bazizidi 2012:254-255; Mokoko 2017:182, 240). They sinned and thereby caused the depravity of the whole of humanity. To amend this situation, God sent his Son, Jesus of Nazareth. ${ }^{18}$ Adam, Eve, Cain and Ham were black, sinned and especially the last drew a curse upon all his black descendants (Melice 2001:42). For this, Simon Kimbangu was sent (Fwd Stockholm 2017-07-09:3; Fwd Stockholm 2015-10-12:1; Mokoko 2017:124, 215-216).

In Kimbanguist thinking, there are implicit parallels between black Africans, especially the Bakongo, and the Jews (Fwd Nkamba 2015-07-15:7; Mokoko 2017:216-217):

The chosen people are the bridge between God and the nations. When God wants to manifest himself to the world, he does it through his people. And when the people and the nations are in need of something, they go through the people of God ... Israel's great difficulty was that they were not really able to do this ... Today, then, God has given the gift and favour to his people ... God has manifested Himself in the Old Testament, today He manifests Himself in us ... He has chosen, called, Simon Kimbangu. He has liberated his people, and what happens today? God among his people ... Here, it is said ozali Nzambe [you are God] but the people have known their God. If the compass points today to the north, today the spiritual

18. One can hear claims that Jesus was black and lived in the Kongo area (Fwd Nkamba 2015-07-13:13-14; see also Fgi Nkamba 2015-07-12:38). However, when I asked the chef spirituel about this, he denied the notion and confirmed that Jesus did live in Palestine (Fwd Nkamba 2015-07-16:6). See also Fwd Stockholm 2019-02-10:3. Yet, in a focus group discussion with leading Kimbanguist theologians, the idea of black Jesus resurfaced, argued with the help of Pope John Paul II's speech on inculturation in Africa, where he referred to God and Jesus as African (Fgi Nkamba 2015-07-12:4). compass points to Nkamba. [Laughs.] People are attracted, they come to Nkamba to recharge. ${ }^{19}$

Both peoples have gone through a history of immense suffering and oppression, and both have received God's incarnations to save people from their sin. However, the Jews turned away from Jesus, which led God to choose the Bakongo as the people amongst whom the next incarnation(s) would take place. ${ }^{20}$ This could be counted as replacement theology. However, even here, the ethnic element overlaps and becomes diluted into the ecclesiastic dimension, because the chosen people can likewise be counted as the Kimbanguists irrespective of their ethnic background (Bazizidi 2012:300-301, 445).

The parallels between Jesus and Simon Kimbangu are explicit despite the differences (Fwd Nkamba 2015-07-10:1; Fwd Stockholm 2017-07-09:4; Molyneux 1990:167-168). Jesus's redemptive role is universal, whereas Simon Kimbangu's redemptive role concentrates on Africa, or actually all descendants of Ham, black people anywhere. A Kimbanguist story about chef spirituel Diangienda's visit to Australia serves to illustrate this point. When the aborigines met him, they wept and asked whether Kimbangu had not come to redeem them, too. Diangienda answered that he did not come only for the Congolese but for them, too (Fwd Stockholm 2017-07-09:3).

This may be the reason why African-American visitors to Nkamba receive special attention, in addition to the fact that their involvement also appears as the fulfilment of Simon Kimbangu's prophesies. ${ }^{21}$ The importance of links to African Americans emphasises the Pan-African nature of Kimbanguism (Mokoko 2017:247-254). This Pan-Africanism covers all people of African origin, wherever they are and however culturally distant from today's Africa they might be. The Pan-African ethos of Kimbanguism appears primarily as the Pan-Africanism of black Africans and their descendants.

Another group attracting special attention in Nkamba are visitors from far away who are not of African descent. When in Nkamba, I was probably interviewed more often - multiple times for TV, radio and press - than I had the opportunity to interview Kimbanguists (Fwd Nkamba 2015-07-15:10, 14). Additionally, there was a photographer following me most of the time, and dozens of people wanted him to take a

19.Fgi Nkamba 2015-07-12:11-12: 'Le peuple de Dieu c'est un pont entre les nations et Dieu. Quand Dieu veut se manifester à travers le monde, il passe par son peuple. et Dieu. Quand Dieu veut se manifester à travers le monde, il passe par son peuple.
Et quand le peuple et les nations ont besoin de quelque chose passe par le peuple de Dieu ... La grande difficulté d'Israël ils ne savaient pas réellement faire ça ... Aujourd'hui et puis Dieu a donné le don et faveur à son peuple ... Dieu s'est manifesté dans l'Ancien Testament, aujourd'hui Dieu se manifeste en nous ... II a choisi, il a appelé Simon Kimbangu. Il a libéré son peuple et aujourd'hui, qu'est-ce qui se passe? Dieu au milieu de son peuple ... [i]ci on dit "Ozali Nzambe" mais là le peuple a connu son Dieu. Si aujourd'hui la boussole indique que le nord, aujourd'hui la boussole spirituelle indique que Nkamba. [En riant.] Les gens ils sont attirés, ils viennent à Nkamba se ressourcer.' (The English translation above, MV.) See also Fgi Nkamba 2015-07-12, 16, 39.

20.The Chef spirituel's account of Kimbanguist salvation history during an audience. Fwd Nkamba 2015-07-16:6. Melice (2001:46-47).

21.Mokoko (2017:249-258); Fwd Stockholm 2014-11-9:13. See also Covington-Ward (2016:3, 38-39); Janzen and MacGaffey (1974:41). When I was in Nkamba, there was a lot of excitement about recent Brazilian visitors, as well (e.g. Fwd Nkamba 2015-07-14:1-2) 
picture with them and me. One popular narrative that I heard several times was about a Korean lady called Kim who saw Simon Kimbangu in a vision. At first, she thought that the dark figure was a demon. However, she became convinced later that he was Kimbangu, previously unknown to her, who proposed that she should visit Nkamba, which she did (Fgi Nkamba 2015-07-12:12-13; Fwd Stockholm 2014-11-9:10).

The international visitors of non-African descent play a different role from that of the African diaspora pilgrims. Both groups can strengthen the image of Kimbanguism's global coverage, but people of non-African origin portray the universal nature of the Kimbanguist mission. The Kimbanguist message is for the whole world. However, despite asking about the matter in different manners, it remained unclear to me what additional value in comparison to Jesus of Nazareth Simon Kimbangu would bring for people not having suffered under Ham's curse.

Universal connections and universal appeal have been of prime importance for the Kimbanguists since the very beginning of their journey as a registered and legal church. The Belgian colonial administration ruthlessly persecuted the Kimbanguists most of the time until the eve of independence(Mokoko 2017:74). Therefore, the Kimbanguists could begin to build up ecumenical connections only in the 1960s. The outcome was that the Kimbanguist Church was admitted to the WCC as the first African Instituted Church in 1964. At that point, the doctrines and organisation of the church were still in the making. The officially recognised doctrine presented to the WCC was much in line with general Protestant or Evangelical theology, with only some specifically Kimbanguist emphases. Simon Kimbangu was presented as a prophet, and the church's official name, Église de Jésus Christ sur la terre par son prophète Simon Kimbangu [the Church of Jesus Christ on Earth by His Prophet Simon Kimbangu], was in line with that. The popular faith, as it was called, considered him to be much more. Gradually, the word prophète [prophet] in the name of the church would be changed to envoyé special/ntumwa [special envoy], which is less defined and allows for different interpretations. Eventually, church practice became such that faith in Simon Kimbangu as an incarnation of the Holy Spirit became the de facto official doctrine. For example, lecturers at the Kimbanguist theological seminary who did not subscribe to this doctrine were removed from office for not following Kimbanguist 'faith and morals'.22

Membership in the WCC was important for the Kimbanguist Church. It was a sign of the Christian quality of their faith. Kimbanguists have always had to defend themselves against claims of syncretism, heresy and being basically a non-Christian religion. This has been the case especially in the DRC, where the traditional mission-established churches have had a suspicious or even negative attitude

22. Simon forthcoming; Balz (2004). Compare to the earlier situation described by Molyneux (1990:170-174). Molyneux's (1990:178) question of whether the Molyneux (1990:170-174). Molyneux's (1990:178) question of whether the
Kimbanguist theological flexibility will remain in the process of increasing Kimbanguist theological flexibility will remain
literalisation must be answered in the negative. towards the Kimbanguists for many decades. Another reason for the importance of WCC membership was that, in that manner, the Kimbanguists have been able to see themselves as an important international player in ecumenical relations. It is a matter of respect and selfesteem. This dimension has been visible, for example, when Kimbanguists have pointed out that they only cooperate with churches belonging to the WCC. Here, the point has been to mark the difference to the other African Initiated Churches. Many of them are now charismatic and pejoratively called 'churches of binzambinzambi [small gods or spirits]' (Fwd Kinshasa 2015-07-18:6-7). Therefore, the WCC decision to cancel the Kimbanguist membership in the organisation in 2020 on doctrinal grounds was a major blow to the self-image of this church (see Simon forthcoming).

\section{The subversive, empowering and multifaceted nature of the Kimbanguist identity}

Identity is always in the making. It never only exists but is negotiated, narrated and enacted all the time. Amongst the Kimbanguists, there are some approaches and techniques of negotiation, narration and enaction that at first seem contradictory but at a closer look reveal a pattern. The Kimbanguists are overtly anticolonial. For example, they keep the memory of Belgian colonial atrocities alive in their ritual life, oral narrations, publications and the large Simon Kimbangu museum in Nkamba. At the same time, however, they still adopt the colonially drawn borders, the existence of races and Christianity, including even some of its most toxic myths, which were used to uphold the colonial system, like the curse of Ham.

This duality of condemning colonialism and adopting its consequences forms a creative third space (Bhabha 2004). Kimbanguists do not engage in a direct fight against the windmills of dominion but rather use its myths, ideologies and organisational structures against the powers that be. The Kimbanguist use of colonial heritage is subversive appropriation: colonial borders become uniting borderscapes instead of separating the people; racial theories and the curse of Ham prove the special position and responsibility of the black race in human history; the white man's religion turns into an inclusive faith when the colonial white Jesus is complemented with a Mukongo incarnation of the Holy Spirit and so on. The tables are turned, and the power of the colony is subverted to construct the Kimbanguist narrative of human history and destiny.

Fitting to their anticolonial stance, the Kimbanguists present themselves, quite logically, as victims of various kinds of colonial atrocities. Yet this victimhood does not rob them of their agency; quite the contrary. Just like their paradigmatic personality, Simon Kimbangu, can be described to have undergone active suffering for the sake of the others, thereby imitating Jesus of Nazareth (Ustorf 1975), so do the 
Kimbanguists place themselves in the position of active victims. In this way, the Kimbanguists assume the role of constructors of their identity. They are active sufferers in the third space.

The resulting identity is radically inclusive in the sense that it appropriates the colonial heritage but combines it with a Kongo religious-political agenda, thereby giving it a liberative twist. In this identity, the Kongo ethnic, Congolese national, Pan-African and universal Christian dimensions of identity are like concentric circles or ripples in the water. ${ }^{23}$ The borders between these dimensions are porous and belonging to the dimensions is not fixed but negotiable.

For the Kimbanguists, decolonial identity does not just happen but is created through rituals, narratives and interaction with the surrounding societies. Whilst the Kimbanguists are very aware of the survival of the colonial structures and ideologies of old, including the colonisation of the mind, it is hard to say to what extent their creation of the third space and the resulting decolonial identity is conscious.

\section{Acknowledgements \\ Competing interests}

The author declares that they have no financial or personal relationships that may have inappropriately influenced them in writing this article.

\section{Author's contributions}

M.V. is the sole author of this research article.

\section{Ethical considerations}

Regionella etikprövningsnämnden Lund, avdelning 3 - Dnr 2015/32.

\section{Funding information}

This research has been funded by the Lund University Centre for Theology and Religious Studies, the Lund Mission Society and the Oscar and Signe Krook Foundation.

\section{Data availability}

In accordance with the Swedish law on sensitive personal data, the data from this study are not publicly available.

\section{Disclaimer}

The views and opinions expressed in this article are those of the author and do not necessarily reflect the official policy or position of any affiliated agency of the author.

23.This concentric picture is very visible in the story of Kimbangu healing people from a distance with his mvuala, praying for Congo, Africa and the whole world (Mokoko 2017:158). See also Mokoko (2017:177) for the chef spirituel as the God-king reigning over these concentric spheres. See also Melice (2001:41). For Kimbanguist inclusivity, see Mangoyo (2007:51).

\section{References}

Anderson, B., 2006, Imagined communities: Reflections on the origin and spread of nationalism, rev. edn., Verso, London.

Andersson, E., 1958, Messianic popular movements in the lower Congo, Almqvist \& Wiksell, Uppsala.

Balz, H., 2004, 'Introductory note', Africa Theological Journal 27(1), 50.

Bazizidi, B., 2012, Simon Kimbangu, une nouvelle ère de l'histoire: Les souvenirs $d u$ christianisme primitive et du judaïsme antique, Editions CORIPROF, Paris.

Bhabha, H., 2004, The location of culture, Routledge, Abingdon.

Brambilla, C. \& Jones, R., 2020, 'Rethinking borders, violence, and conflict: From sovereign power to borderscapes as sites of struggles', Society and Space 38(2), 287-305. https://doi.org/10.1177/0263775819856352

Covington-Ward, Y., 2016, Gesture and power: Religion, nationalism, and everyday performance in Congo, Duke University Press, Durham.

Diangienda, J. [Kuntima], 1984, L'histoire du kimbanguisme, Editions E.KI, ChâtenayMalabry.

Elden, S., 2009, Terror and territory: The spatial extent of sovereignty, University of Minnesota Press, Minneapolis, MN.

Hobsbawm, E.J., 1992, Nations and nationalism since 1780, 2nd edn., Cambridge University Press, Cambridge.

Hochschild, A., 1999, King Leopold's ghost: A story of greed, terror, and heroism in Colonial Africa, Macmillan, London.

Hunt, N.R., 2016, A nervous state: Violence, remedies, and reverie in Colonial Congo, Duke University Press, Durham.

Janzen, J.M. \& MacGaffey, W., 1974, An anthology of Kongo religion: Primary texts from Lower Zaïre, University of Kansas, Lawrence, KS.

Kilansi Kia Kongo Dia Kati, 2018, viewed 15 May 2018, from http://www. africafederation.net/Kongo_Central.htm.

Kina-Kuntala, P., 2009, Nkamba, ville sainte du kimbanguisme, s.n., Valencia.

Knust, J., 2014, 'Who's afraid of Canaan's curse? Genesis 9:18-29 and the challenge of reparative reading', Biblical Interpretation 22, 388-413. https://doi org/10.1163/15685152-02245p02

'Le kimbanguisme, jeune religion née au Congo, 2017', La Croix l'hebdo, viewed 14 February 2021, from https://www.la-croix.com/Monde/Le-kimbanguismejeune-religion-nee-Congo-2017-05-26-1300850276.

Likaka, O., 2009, Naming colonialism: History and collective memory in the Congo, 1870-1960, The University of Wisconsin Press, Madison, WN.

MacGaffey, W., 1969, 'The beloved city: Commentary on a Kimbanguist text', Journal of Religion in Africa 2(2), 129-147. https://doi.org/10.1163/157006 $669 \times 00082$

MacGaffey, W., 1983, Modern Kongo Prophets, Indiana University Press, Bloomington, IN

Mangoyo, J., 2000, 'Notions trinitaires dans les religions et doctrine du Saint-Esprit dans l'église kimbanguiste à la lumière de l'histoire et des saintes écritures', unpublished paper, s.l.

Mangoyo, J., 2003, 'Le kimbanguisme: La reconquete de la dignité perdue par une race humaine', unpublished paper, s.l.

Mangoyo, J., 2007, 'La base commune de l'œcuménisme chrètien: la foi en la sainte trinité', unpublished paper, s.I.

Mangoyo, J., n.d., 'Simon Kimbangu et ses propheties', unpublished paper, s.l.

Martin, M.-L., 1971, Die Kirche ohne Weiße, Friedrich Reinhardt Verlag, Basel.

Melice, A., 2001, 'Le kimbanguisme: un millénarisme dynamique de la terre aux cieux', Bulletin des Séances d'Académie royale des Sciences d'Outre-Mer 47 (Suppl.), 35-54.

Mokoko, A. [Gampiot], 2017, Kimbanguism: An African understanding of the Bible, Pennsylvania University Press, University Park, PN.

Molyneux, G., 1990, 'The place and function of hymns in the EJCSK', Journal of Religion in Africa 20(2), 153-187. https://doi.org/10.1163/157006690X00114

Mpassi, J., 2009, 'Preface', in P. Kina-Kuntala (ed.), Nkamba, ville sainte du kimbanguisme, pp. 7-8, s.n., Valencia.

Nzongola-Ntalaja, G., 2002, The Congo: From Leopold to Kabila: A people's history, Zed Books, London.

Pemberton, J., 1993, 'The history of Simon Kimbangu, Prophet, by the Writers Nfinangani and Nzungu, 1921: An introduction and annotated translation', Journal of Religion in Africa 23(3), 194-231. https://doi. org/10.2307/1581107

Sanderson, J.-P., 2000, 'Le Congo belge entre mythe et réalité: Une analyse du discours démographique colonial', Population (French edition) 55(2), 331-355. https://doi. org/10.2307/1535036

Simon, B., forthcoming, Genese einer Religion: Der Kimbanguismus und sein Abdschied von der Okumene, Evangelische Verlagsanstalt, Leipzig.

Thornton, J., 1998, The Congolese Saint Anthony: Dona Beatriz Kimpa Vita and the Antonian Movement 1684-1706, Cambridge University Press, Cambridge.

Ustorf, W., 1975, Afrikanische initiative: Das aktive Leiden des Propheten Simon Kimbangu, Herbert, Lang, Bern. 